\title{
Isolation and Characterization of a Cellulolytic Microorganism, Cellulomonas fermentans sp. nov.
}

\author{
C. BAGNARA, ${ }^{*}$ R. TOCI, C. GAUDIN, AND J. P. BELAICH \\ Laboratoire de Chimie Bactérienne, Centre National de la Recherche Scientifique, 13277 Marseille Cedex 9,* and \\ Université de Provence, Marseille, France
}

\begin{abstract}
A new mesophilic, cellulolytic microorganism was isolated from a municipal dumping ground. The isolation of this bacterium was performed under anaerobic conditions, but its growth was similar under both anaerobic and aerobic conditions. This gram-positive, nonmotile, coryneform rod, with a high $(75.8$ mol\%) guanineplus-cytosine content in deoxyribonucleic acid (DNA), can grow on numerous carbon sources. The fermentation products are acetic acid, ethanol, formic acid, succinic acid, $\mathrm{CO}_{2}$, and, occasionally, lactic acid. Nucleic acid hybridization tests between the DNA of the isolate and the DNA of Cellulomonas uda ATCC 21399 showed some partial ( 37 to $40 \%$ ) relatedness. This information, in addition to other data, suggests that this organism belongs to the genus Cellulomonas, and it is proposed here as a new species, Cellulomonas fermentans sp. nov. The type strain is M (DSM 3133).
\end{abstract}

The utilization of solid municipal waste is of interest from both economic and pollution abatement points of view. Among the methods proposed so far for waste disposal purposes are composting and anaerobic digestion $(26,35)$. In municipal dumping grounds, spontaneous methane production has been found to occur. Because municipal refuse contains as much as $50 \%$ paper (1) in addition to other cellulosic substrates, cellulose mineralization is probably an important part of the decomposition process.

A cellulolytic bacterium was isolated under anaerobic conditions from an ecosystem of this type. This paper reports how it was identified and characterized.

\section{MATERIALS AND METHODS}

Media and culture conditions. The basal medium used had the following composition: $\mathrm{K}_{2} \mathrm{HPO}_{4}, 2.21 \mathrm{~g} ; \mathrm{KH}_{2} \mathrm{PO}_{4}, 1.50 \mathrm{~g}$; $\left(\mathrm{NH}_{4}\right)_{2} \mathrm{SO}_{4}, 1.30 \mathrm{~g} ; \mathrm{MgCl}_{2} \cdot 6 \mathrm{H}_{2} \mathrm{O}, 0.10 \mathrm{~g} ; \mathrm{CaCl}_{2} \cdot 2 \mathrm{H}_{2} \mathrm{O}, 0.02$ $\mathrm{g}$; $\mathrm{FeSO}_{4}$ solution $(0.5 \%$ [wt/vol]), $0.25 \mathrm{ml}$; yeast extract, $5 \mathrm{~g}$; and distilled water to bring the final volume to 1 liter. The $\mathrm{pH}$ was adjusted to 7.4 with $8 \mathrm{~N} \mathrm{NaOH}$.

For isolation purposes, the basal medium was supplemented with $4.0 \%$ (wt/vol) ball-milled MN300 cellulose and $2.0 \%$ agar and used by the Hungate roll-tube technique (19).

For anaerobic cultures in liquid medium, after autoclaving $\left(30 \mathrm{~min}, 120^{\circ} \mathrm{C}\right), 10 \mathrm{ml}$ of sterile cysteine-hydrochloride solution $(5.0 \%)$ and $10 \mathrm{ml}$ of sterile sodium bicarbonate solution $(8.0 \%)$ per liter were added. The anaerobic culture technique used was that of Hungate (18) as modified by Bryant (7). Hungate anaerobic tubes were used for $10-\mathrm{ml}$ cultures. For more voluminous cultures, we used special flasks (Schott) sealed with butyl rubber stoppers and screw caps.

When carbon sources were soluble carbohydrates, they were autoclaved separately $\left(30 \mathrm{~min}, 110^{\circ} \mathrm{C}\right)$ and added just before inoculation.

For culture maintenance, the basal medium was supplemented with $0.5 \% \mathrm{MN} 300$ cellulose and dispensed in $10-\mathrm{ml}$ volumes into Hungate tubes under an $\mathrm{O}_{2}$-free argon atmosphere.

All cultures were incubated at $30^{\circ} \mathrm{C}$ without agitation.

Isolation procedures. Strain $\mathrm{M}^{\mathrm{T}}$ was obtained by enrich-

\footnotetext{
* Corresponding author.
}

ment and isolation of bacteria from Montaubert (Essonne, France) municipal dumping ground samples taken at the depth of $23 \mathrm{~m}$.

Enrichment culture was initiated by the inoculation of about $15 \mathrm{~g}$ of sample into a $250-\mathrm{ml}$ culture flask which contained $100 \mathrm{ml}$ of basal medium supplemented with $8 \%$ barley straw, under anaerobic conditions.

We ascertained that methane production occurred during the 5 weeks of incubation.

Serial dilutions in $25 \mathrm{mM}$ phosphate buffer from sterile samples of this culture were then prepared and used to inoculate cellulose agar roll tubes. After 2 weeks, colonies developing cleared zones of cellulose digestion were individually transferred into liquid basal medium supplemented with $0.2 \%$ cellobiose. This procedure was repeated a few more times to ascertain the purity of the culture by colonytype homogeneity and microscopic examination.

Morphology. Living and stained cells were examined by light microscopy.

For electron microscopy, a 2-day-old culture grown on $0.2 \%$ cellobiose was used. After dilution of the culture in distilled water, a drop of the cell suspension was placed on a Formvar-coated copper grid, and the preparation was fixed and stained with a drop of $1 \%$ phosphotungstic acid solution.

For thin-section preparation, cells were fixed in glutaraldehyde and $\mathrm{OsO}_{4}$ as described by Ryter and Jacob (24), dehydrated, and embedded in araldite. Thin sections were contrasted with uranyl acetate and lead citrate.

Growth measurements. Growth on soluble carbohydrate medium was measured by optical density $(450 \mathrm{~nm})$. For growth on cellulose, the pellet proteins were determined as described by Bensadoun and Weinstein (2), using bovine serum albumin as the standard.

Temperature and pH for optimal growth. Basal medium supplemented with $0.2 \%$ cellobiose was used to determine the optimal growth temperature. For each temperature tested, five tubes, each containing $10 \mathrm{ml}$ of medium, were inoculated with $5 \%(\mathrm{vol} / \mathrm{vol})$ of a 2-day-old culture grown on a similar medium at $30^{\circ} \mathrm{C}$. Optical densities were read directly at $450 \mathrm{~nm}$ on a Pye Unicam spectrophotometer. The growth rate average was calculated for each temperature tested.

For $\mathrm{pH}$ studies, a modified basal medium supplemented with $0.2 \%$ cellobiose was used; phosphate buffer was re- 
placed by $200 \mathrm{mN}$ MOPS buffer (morpholinepropanesulfonic acid) $-5 \mathrm{mM} \mathrm{KH} \mathrm{KHO}_{4}$. Cultures $(50 \mathrm{ml})$ with $\mathrm{pH}$ adjusted from 6 to 8 (by increments of $0.4 \mathrm{pH}$ units) just before sterilization were inoculated with a 2-day-old culture grown in the same medium. Growth measurements were performed after sterile sampling on a Kontron spectrophotometer (model Uvikon 810). The $\mathrm{pH}$ was checked in each sample, and it did not decrease more than 0.1 unit from the initial $\mathrm{pH}$. The growth rate average was calculated for each $\mathrm{pH}$ tested.

Physiological tests. (i) Nutritional requirements. To determine amino acid and vitamin requirements, yeast extract from the maintenance broth was extensively diluted by four successive transfers into yeast extract-free basal medium supplemented with $0.2 \%$ cellobiose (cellobiose minimal medium $[C M M])$ before inoculation. Volumes $(100 \mathrm{ml})$ of the nine following media were inoculated: CMM, CMM plus biotin $(0.2 \mathrm{mg} /$ liter $)$ plus thiamine $(0.5 \mathrm{mg} / \mathrm{liter}), \mathrm{CMM}$ plus vitamin cocktail $(0.2 \mathrm{ml} / \mathrm{liter}), \mathrm{CMM}$ plus vitamin-free Casamino Acids (0.2\%), and CMM plus various yeast extract concentrations $(0.01,0.05,0.1,0.2$, and $0.5 \%)$. The composition of the vitamin cocktail was $p$-aminobenzoic acid $(0.025 \mathrm{~g})$, biotin $(0.01 \mathrm{~g})$, nicotinamide $(0.015 \mathrm{~g})$, panthothenic acid $(0.025 \mathrm{~g})$, cyanocobalamin $(0.01 \mathrm{~g})$, and distilled water to obtain $100 \mathrm{ml}$. Yeast extract and Casamino Acids were autoclaved in the medium, and vitamins sterilized by filtration were then added aseptically.

(ii) Carbon source utilization. Basal medium with only $0.05 \%$ yeast extract was used to test for the utilization of numerous substrates as sole carbon source. These substrates were autoclaved separately and added to the sterile medium to give a final concentration of $0.2 \%$. Control cultures were grown on the medium with no other carbon source, and each test was carried out in duplicate.

(iii) Biochemical tests. Catalase and nitrate reduction tests were conducted as described by Holding and Collee (17). For catalase production, a comparative test was performed on nutrient agar in a petri dish between strain $\mathbf{M}^{\mathrm{T}}$ and Cellulomonas uda ATCC 21399 (catalase positive). Nitrate reduction was tested in basal medium containing $0.1 \%$ $\mathrm{KNO}_{3}$.

To test cytochrome oxidase, gelatinase, and $\beta$-galactosidase, Biomerieux (France) methods and reagents were used.

Ammonia production from peptone was tested as described by Stackebrandt and Kandler (29), and indole production was tested as described by Holdeman et al. (16).

(iv) Fermentation end-product analyses. Culture samples were centrifuged for $20 \mathrm{~min}$ at $12,000 \times g$. The supernatants obtained were used for determining alcohols and acids.

Ethanol, acetic acid, and L-(+)-lactic acid were determined spectrophotometrically with the appropriate enzyme kit (Boehringer GmbH, Mannheim, Federal Republic of Germany). Formic acid was determined by the colorimetric method of Lang and Lang (21).

Succinic acid and acetylmethylcarbinol were assayed with a Girdel gas chromatograph fitted with a Chromosorb 101 (80/100 mesh) column ( $1.5 \mathrm{~m}$ long by $6.4 \mathrm{~mm}$ in diameter). The chromatograph was fitted with a flame ionization detector, and the following conditions were selected for the analysis: carrier gas, 1.2 bar $\left(1.210^{5} \mathrm{~Pa}\right)$ of argon at the entrance to the column; injector and detector temperatures, $250^{\circ} \mathrm{C}$.

For succinic acid evaluation, a $0.25-\mathrm{ml}$ sample was methylated as described by Holdeman et al. (16), and $1 \mu l$ of the methylated sample was injected into the gas chromatograph. The column temperature was $210^{\circ} \mathrm{C}$.
For acetylmethylcarbinol evaluation, a $0.25-\mathrm{ml}$ sample was acidified with $25 \mu \mathrm{l}$ of $12 \mathrm{~N} \mathrm{HCl}$, and $1 \mu \mathrm{l}$ of acidified supernatant was injected into the gas chromatograph. The column temperature was $160^{\circ} \mathrm{C}$.

Gases were analyzed by removing a sample $(0.5 \mathrm{ml})$ from the headspace of a culture tube with a 1-ml syringe and injecting it into a Girdel chromatograph fitted with a thermoconductivity detector $(100 \mathrm{~mA})$ and silica gel and molecular sieve columns (both $3.2 \mathrm{~mm}$ in diameter and $1.5 \mathrm{~m}$ long). For both columns, the temperature was $80^{\circ} \mathrm{C}$, and the carrier gas was argon at a pressure of $1.0 \mathrm{bar}\left(1.010^{5} \mathrm{~Pa}\right)$ at the entrance to the column. The injection and detector temperatures were $150^{\circ} \mathrm{C}$.

Cell wall amino acid analysis. Fully hydrolyzed cell wall material was prepared from approximately $10 \mathrm{mg}$ (dry weight) of cells by the hot trichloroacetic acid-trypsin rapidscreening method of Schleifer and Kandler (25). Chromatography of amino acids was performed with the twodimensional thin-layer chromatography system described by Harper and Davis (15).

Cell wall carbohydrate analysis. The method described by Staneck and Roberts (32) was used for cell wall carbohydrate analysis.

DNA base composition and hybridization. (i) Preparation of DNA and analysis of DNA base composition. The method described by Stackebrandt and Kandler (29) was used for the preparation of the deoxyribonucleic acid (DNA). The melting temperature of the purified DNA was determined with a Perkin-Elmer spectrophotometer (model 551) by the method of Mandel and Marmur (23), and the guanosine-plus-cytosine $(\mathrm{G}+\mathrm{C})$ content was calculated. The accuracy of the method was determined with DNA of Micrococcus lysodeikticus $(\mathrm{G}+\mathrm{C}, 72 \mathrm{~mol} \%)$ and of Escherichia coli $(\mathrm{G}+\mathrm{C}, 50 \mathrm{~mol} \%)$ as standards.

Labeled DNA was extracted from cells which were cultivated in basal medium supplemented with $0.2 \%$ cellobiose (as for unlabeled DNA) and $1 \mathrm{mCi}$ of $\left[{ }^{3} \mathrm{H}\right]$ thymidine per 300 $\mathrm{ml}$ of medium. Cells were harvested at the end of the log phase and disrupted with glass beads (diameter, 0.45 to 0.50 $\mathrm{mm}$ ) in a Braun breaking apparatus for $2 \mathrm{~min}$ at a breaking speed of 1,500 oscillations per min, and then the DNA was purified by the same method as that used for unlabeled DNA.

All DNA concentrations were determined by measuring absorbance at $260 \mathrm{~nm}$.

The specific radioactivity of the ${ }^{3} \mathrm{H}$-labeled DNA obtained ranged between $14 \times 10^{3}$ and $43 \times 10^{3} \mathrm{cpm} / \mu \mathrm{g}$ of DNA.

(ii) Preparation of DNA filter. Denatured unlabeled DNA was prepared by the method of Birnstiel et al. (4), and DNA filters were made as described by Stackebrandt and Kandler (29). Nitrocellulose membrane filters (25-mm diameter; $0.22-\mu \mathrm{m}$ pore size [type GSWP; Millipore Corp., Bedford, Mass.]) were used. The binding efficiency of the DNA to nitrocellulose filters ranged between 84 and $95 \%$ of the DNA input.

For the experiments, four small identical filters, each containing about $37 \mu \mathrm{g}$ of DNA, were cut out of one filter.

(iii) Hybridization procedure. For fragmentation, solutions of labeled DNA were sonically treated (three times $15 \mathrm{~s}$ with 15-s intervals) with a Sonifier (model S110; Branson Sonic Power Co., Danbury, Conn.) at 50\% intensity.

Sonically treated DNA $(10 \mu \mathrm{g} / \mathrm{ml}$ of $0.1 \times \mathrm{SSC}[1 \times \mathrm{SSC}$ is $0.15 \mathrm{M} \mathrm{NaCl}$ plus $0.015 \mathrm{M}$ trisodium citrate] [pH 7.0]) was denatured by heating at $110^{\circ} \mathrm{C}$ for $10 \mathrm{~min}$ and then rapidly chilled on ice. The procedure used for DNA-DNA hybridization was that described by Stackebrandt and Kandler 
(29). Incubation was performed for $24 \mathrm{~h}$ at $47^{\circ} \mathrm{C}$ in a water bath (Salvis) with gentle reciprocal agitation ( 25 movements per min) to reduce the possibility of a concentration gradient of radioactive DNA fragments being formed as described by Johnson and Ordal (20).

Each reaction was run in sextuple. Negative controls (filters bearing calf thymus DNA) were included for each labeled DNA tested.

At the end of the incubation period, the reaction mixtures were removed, and the filters were washed twice with cold 3 $\times$ SSC and dried in a vacuum oven at $70^{\circ} \mathrm{C}$. For each hybridization test, the reaction mixture, washed solutions, and filter were counted by using a model SL 4000 liquid scintillation system (Intertechnic, Kontron S.A.) and a pseudocumene-based scintillation fluid (HP/b; Beckman Instruments, Inc., Fullerton, Calif.). For each test, the proportion of radioactive DNA bound to filter DNA was estimated, and then the DNA homology values were calculated (mean percentage of heterologous binding compared with homologous binding).

Enzymes, standard DNA, and radioisotopes. Proteinase K was purchased from E. Merck AG, Darmstadt, Federal Republic of Germany. Lysozyme, ribonuclease A, calf thymus DNA (type I), $E$. coli B DNA (type VIII) and $M$. lysodeikticus DNA (type XI) were obtained from Sigma Chemical Co., St. Louis, Mo. $\left[{ }^{3} \mathrm{H}\right]$ thymidine $(25 \mathrm{Ci} / \mathrm{mmol})$ was purchased from C.E.A., Saclay, France.

\section{RESULTS}

The enrichment and isolation procedure yielded a pure culture of a cellulolytic organism ( strain $\mathrm{M}^{\mathrm{T}}$ ). Colonies of the isolate on cellulose agar measured about $1.5 \mathrm{~mm}$ after 7 days of incubation at $30^{\circ} \mathrm{C}$. After 2 weeks, these colonies were circular, approximately 2 to $3 \mathrm{~mm}$ in diameter, and white, and they had an undulate margin. Zones of 1 to $2 \mathrm{~mm}$ of cellulose digestion extending from the colony periphery were clearly visible.

The microscopy studies showed that the isolate is a rod-shaped, coryneform, nonmotile bacterium occurring mostly singly and in pairs ( $\mathrm{V}$ forms) and exhibiting a polymorphism: club-shaped rods and rods of various lengths (Fig. 1A).

Cells in the exponential growth phase were gram negative (36), but transmission electron microscopy of thin sections of this strain showed the cell wall profile and ultrastructural details typical of gram-positive-type organisms (Fig. 1B). It was therefore possible to estimate the dimensions of the cells: 0.2 to 0.5 by 0.6 to $1.7 \mu \mathrm{m}$.

Growth of the new isolate was similar under both anaerobic and aerobic conditions with shaking on $0.2 \%$ cellobiose. Under both conditions, the biomass increase was similar (change in absorbance at $450 \mathrm{~nm}$ : 1.5 and 2.0 , respectively), and fermentation products accumulated. The

TABLE 1. Comparison of growth on cellobiose ( $2 \mathrm{~g} /$ liter) under anaerobic and aerobic conditions

\begin{tabular}{lcccc}
\hline \multirow{2}{*}{$\begin{array}{c}\text { Culture } \\
\text { condition }\end{array}$} & $\Delta A_{450}{ }^{a}$ & \multicolumn{3}{c}{$\begin{array}{c}\text { Fermentation product (mol/mol of } \\
\text { hexose consumed) }\end{array}$} \\
\cline { 3 - 5 } & & Acetate & Formate & Ethanol \\
\hline Anaerobic & 1.5 & 0.73 & 0.90 & 0.37 \\
Aerobic & 2.0 & 0.44 & 0.16 & 0.04 \\
\hline
\end{tabular}

${ }^{a} A_{450}$, Absorbance at $450 \mathrm{~nm}$.

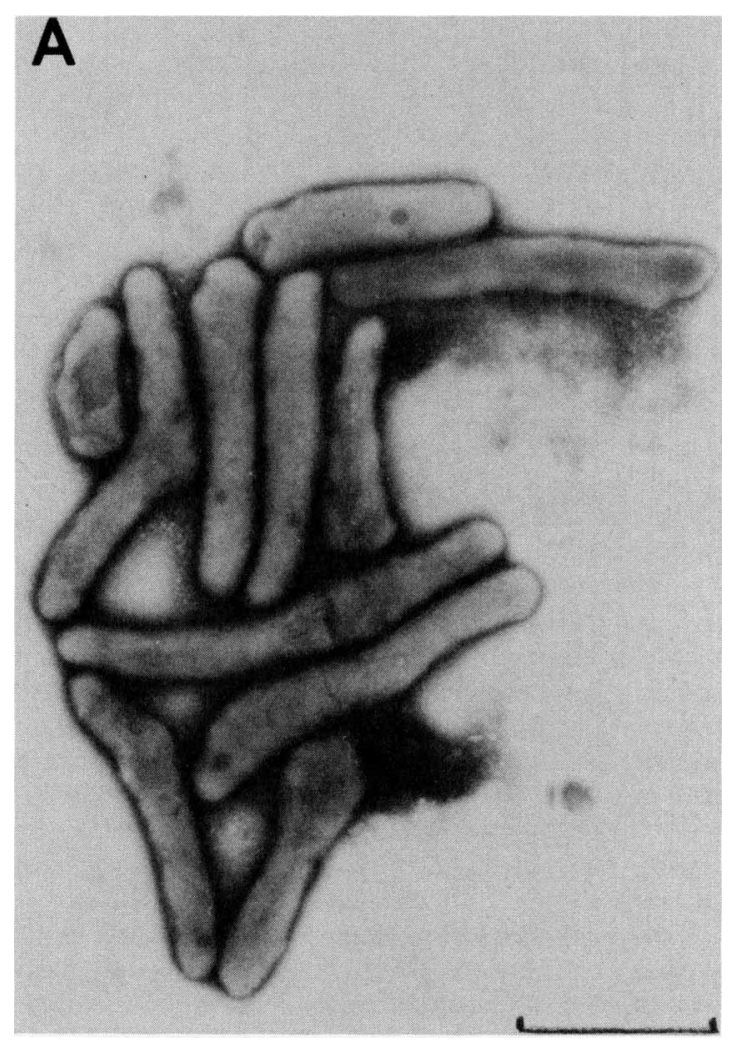

FIG. 1. Electron micrographs of cells of strain $\mathbf{M}^{\mathrm{T}}$ grown on basal medium supplemented with $0.2 \%$ cellobiose for 2 days. (A) Negative staining; bar $=1 \mu \mathrm{m}$. (B) Thin section; bar $=0.1 \mu \mathrm{m}$.

three main fermentation products detected under anaerobic conditions (acetate, formate, and ethanol) were also estimated in the culture supernatant from aerobic growth (Table 1). The results seem to indicate that this strain does not have a classical oxydative metabolism and derives its energy essentially from fermentation metabolism under aerobic growth conditions.

Yeast extract at the minimum concentration of $0.05 \%$ was necessary for optimum growth. It could be replaced by Casamino Acids ( $0.2 \%$ [wt/vol]) and, less efficiently, with a vitamin cocktail. A mixture of biotin and thiamine was not sufficient to ensure growth.

The isolate grew under both aerobic and anaerobic conditions on a wide variety of substrates, including cellulose, cellobiose, glucose, and raffinose, but not on ribose, and it utilized acetate under aerobic conditions but not lactate and gluconate. (The extensive list of nutrients used is given in the taxonomic description at the end of the discussion.)

The metabolic products detected in cellulose culture after 15 days of fermentation were acetic acid, formic acid, and ethanol. In addition, carbon dioxide and succinic acid were produced in smaller amounts, and occasionally $\mathrm{L}_{-}-(+)$-lactic acid. No acetylmethylcarbinol was produced, and no $\mathrm{H}_{2}$ was evolved. Strain $\mathrm{M}^{\mathrm{T}}$ produced $\mathrm{NH}_{3}$ from peptone, nitrate reductase, cytochrome oxidase, gelatinase, and $\beta$-galactosidase but failed to produce indole, catalase, or urease.

Alanine and ornithine are present in the strain $\mathbf{M}^{\mathrm{T}}$ cell wall, and its main sugar component is glucose, but rhamnose and ribose are also present.

The DNA base composition is $75.8 \mathrm{~mol} \% \mathrm{G}+\mathrm{C}$ (mean from two experiments).

The isolate showed a DNA homology of 37 to $40 \%$ with 


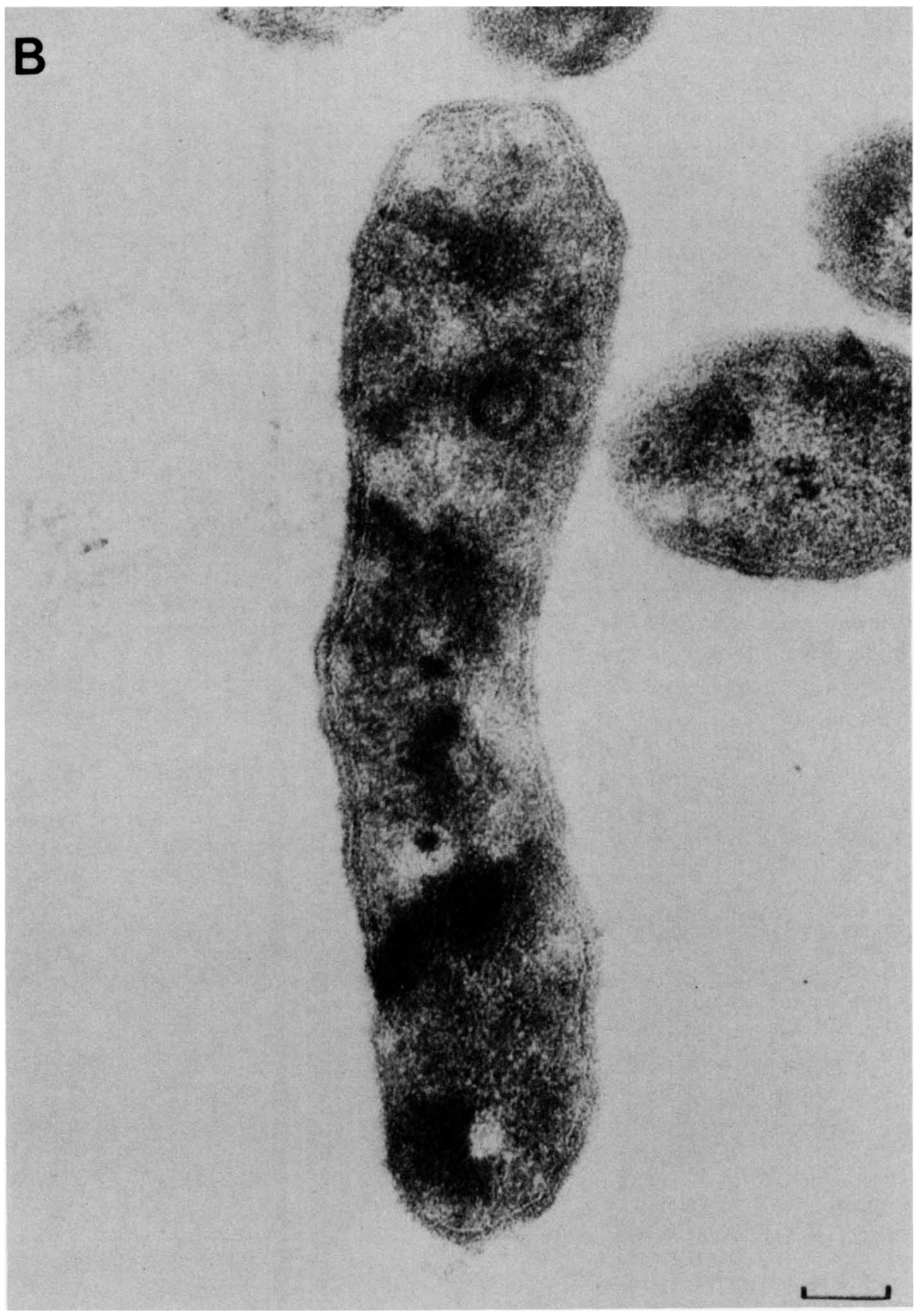

Cellulomonas sp. ATCC 21399 (DSM 20108) which was assimilated to $C$. uda (Kellermann et al. [3]) by Stackebrandt and Kandler (28) (Table 2).

\section{DISCUSSION}

Based on its morphological and other characteristics, the gram-positive, nonsporeforming, coryneform, cellulosedecomposing bacterium described herein belongs to the family Corynebacteriaceae (8). Several studies have been performed with a view to characterizing the various genera of this family by using various approaches, including numerical taxonomy studies $(5,11,12,34)$. They have led to contradictory results, and some cellulolytic strains have been classified as belonging to genera other than Cellulomonas.
Studies on the Cellulomonas genus subsequently showed that certain characters such as the peptidoglycan type of the cell wall (13), the $G+C$ content of the DNA (37), the fermentation pattern (28), serological properties (6), isoprenoid quinones $(10,38)$, and DNA homology $(27,29)$ demonstrated the homogeneity of this genus. Differences between the various known strains have clearly demonstrated the existence of eight species in this genus $(24,26)$, despite the fact that only one species was recognized in the 1974 edition of Bergey's manual (8).

From these studies, it appears that the most salient features defining members of the genus Cellulomonas are its cellulolytic aptitude and the high $\mathrm{G}+\mathrm{C}$ content of its DNA ( 71 to $77 \mathrm{~mol} \%$ ). The new isolate fulfilled both these criteria. In addition, its DNA homology ( 37 to $40 \%$ ) with a strain of Cellulomonas sp. confirmed that it belongs to this genus. 
Indeed, it can be seen (Table 2) that the range of DNA homologies between several established species of Cellulomonas is 12 to $50 \%$. However, in contrast with previously described Cellulomonas species, aerobiosis did not offer any energetic advantage for its growth, and the strain was thought to probably derive its energy essentially from fermentation processes although placed under aerobic conditions. Furthermore, the combined morphological and biochemical characteristics of this organism (especially the cell wall sugars and the utilization of certain carbon sources, as pointed out by Stackebrandt and Kandler [29]), do not match the definitions of any of the known species (Table 3). Biotin and thiamine were not the sole growth-promoting factors required by the strain as commonly reported for Cellulomonas strains (8). Nevertheless, similar growth requirements were found for several Cellulomonas strains (9, 33) and C. uda ATCC 21399 (14), in which small amounts of yeast extract added to the basal medium greatly enhanced growth.

We therefore propose the establishment of a new species, Cellulomonas fermentans, sp. nov. (Fer.men'tans. L.part.adj. fermentans fermenting) with the following specific description.

Morphology. Coryneform rod exhibiting a polymorphism, 0.2 to 0.5 by 0.6 to $1.7 \mu \mathrm{m}$. Nonmotile. Gram positive.

Colony characteristics. White with an undulate margin, 2 to $3 \mathrm{~mm}$ in diameter. A zone of cellulose digestion extending from the periphery of the colony is observed in cellulose agar.

Physiology. Anaerobic, but with growth under aerobic conditions without any apparent benefit. Growth on arabinose, cellulose, fructose, galactose, glucose, glycogen, lactose, maltose, mannose, mannitol, raffinose, starch, sucrose, trehalose, xylose, and xylan but not on asparagine, arbutine, glycerol, inulin, melibiose, melezitose, pectin, rhamnose, ribose, pyruvate, salicin, sorbitol, and urea. It does not grow under aerobic conditions on butanol, butyrate, citrate, ethanol, gluconate, lactate, propanol, propionate, or succinate but grows slowly on acetate. Yeast extract $(0.05 \%)$ and Casamino Acids $(0.2 \%)$ support only slight growth. Growth factors other than biotin and thiamine together are required and can be provided by $0.05 \%$ yeast extract.

TABLE 2. DNA homology between the new isolate and $C$. uda ATCC 21339 compared with DNA homologies among various Cellulomonas spp.

\begin{tabular}{lcc}
\hline \multirow{2}{*}{ Source and strain } & \multicolumn{2}{c}{$\begin{array}{c}\left.{ }^{3} \mathrm{H}\right] \mathrm{DNA} \text { homology }(\%)^{a} \text { with filter } \\
\text { DNA from }\end{array}$} \\
\cline { 2 - 3 } & $\begin{array}{c}\text { C. uda ATCC } \\
21399\end{array}$ & New isolate \\
\hline $\begin{array}{l}\text { Present study } \\
\text { C. uda ATCC 21399 }\end{array}$ & 100 & 37 \\
New isolate & 40 & 100 \\
Reference 29 & & \\
C. uda ATCC $491^{\mathrm{T}}$ & 90 & \\
C. fimi & $34-39$ & \\
C. biazotea & 27 & \\
C. gelida & $43-49$ & \\
C. cartae & 12 & \\
C. cellasea & 27 \\
\hline
\end{tabular}

"Homology index is expressed as the percentage (mean of six experiments) of $\left[{ }^{3} \mathrm{H}\right] \mathrm{DNA}$ bound to a particular filter DNA, relative to the homologous reaction.

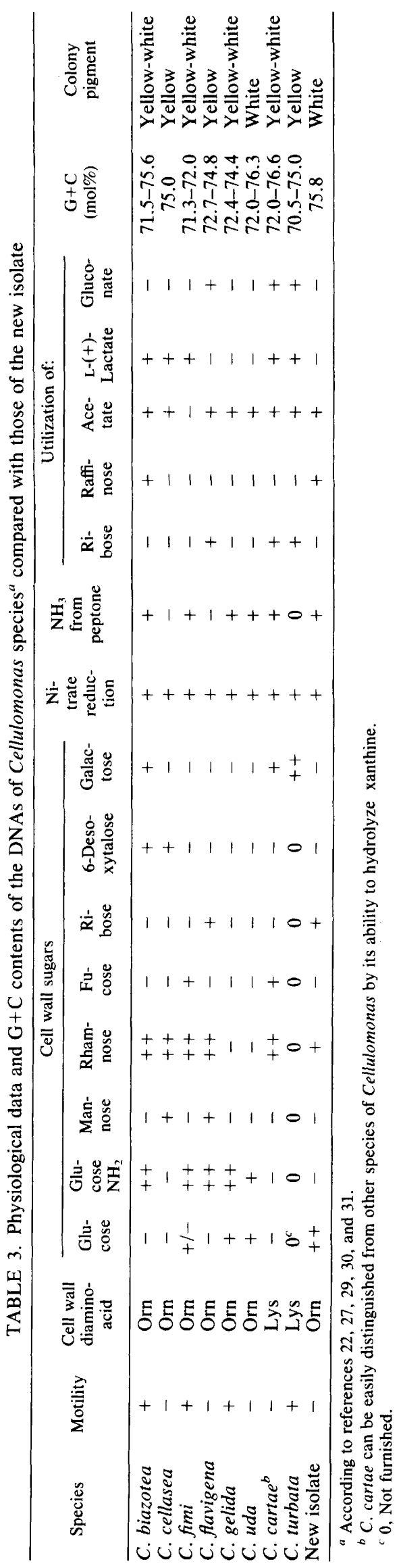


Fermentation products. Fermentation products are acetic acid, formic acid, ethanol, occasionally $\mathrm{L}-(+)$-lactic acid, and, in smaller amounts, carbon dioxide and succinic acid.

Biochemical reactions. Gelatin liquefied, nitrate reduced, $\mathrm{NH}_{3}$ produced from peptone. Neither acetyl methyl carbinol nor indole is produced. Catalase and urease negative.

Temperature relationships. Optimum temperature between 30 and $37^{\circ} \mathrm{C}$. No growth at $50^{\circ} \mathrm{C}$.

pH relationships. Optimum $\mathrm{pH}$ around 7.4 . Growth rate decreases substantially under 7 and over 8 .

Cell wall structure. Ornithine is the diamino acid of the peptidoglycan. Cell wall sugars are glucose, rhamnose, and ribose.

DNA base composition. $75.8 \mathrm{~mol} \% \mathrm{G}+\mathrm{C}$.

Source. Methanogenic enrichment culture from a municipal dumping ground was the source.

Type strain. Strain $\mathbf{M}^{\mathrm{T}}$. This strain has been deposited in the Deutsche Sammlung von Mikroorganismen (DSM) under accession number 3133 .

\section{ACKNOWLEDGMENTS}

This research was funded by the company Gaz de France, the Centre National de al Recherche Scientifique, and Université de Provence.

We thank P. Thomas (Laboratoire de différentiation cellulaire, Centre Universitaire de Luminy, Marseille, France) for performing the electron microscopy.

\section{LITERATURE CITED}

1. American Public Works Association. 1961. Municipal refuse disposal. American Public Works Association, Danville, Ill.

2. Bensadoun, A., and D. Weinstein. 1976. Assay of proteins in the presence of interfering materials. Anal. Biochem. 20:241-250.

3. Bergey, D. H., R. S. Breed, R. W. Hammer, F. C. Harrison, and F. M. Huntoon. 1923. Bergey's manual of determinative bacteriology, 1st ed. The Williams \& Wilkins Co., Baltimore.

4. Birnstiel, M. L., B. H. Sells, and I. F. Purdom. 1972. Kinetic complexity of RNA molecules. J. Mol. Biol. 63:21-39.

5. Bousfield, I. J. 1972. A taxonomic study of some coryneform bacteria. J. Gen. Microbiol. 71:441-445.

6. Braden, A. R., and D. W. Thayer. 1976. Serological study of Cellulomonas. Int. J. Syst. Bacteriol. 26:123-126.

7. Bryant, M. P. 1972. Commentary on the Hungate technique for culture of anaerobic bacteria. Am. J. Clin. Nutr. 25:1324-1328.

8. Buchanan, R. E., and N. E. Gibbons (ed.). 1974. Bergey's manual of determinative bacteriology, 8 th ed. The Williams \& Wilkins Co., Baltimore.

9. Choi, W. Y., K. D. Haggett, and N. W. Dunn. 1978. Isolation of a cotton wool degrading strain of Cellulomonas: mutants with altered ability to degrade cotton wool. Aust. J. Biol. Sci. 31:553-564.

10. Collins, M. D., M. Goodfellow, and D. E. Minnikin. 1979. Isoprenoid quinones in the classification of coryneform and related bacteria. J. Gen. Microbiol. 110:127-136.

11. Da Silva, G. A. N., and J. G. Holt. 1965. Numerical taxonomy of certain coryneform bacteria. J. Bacteriol. 90:921-927.

12. Davis, G. H. G., and K. G. Newton. 1969. Numerical taxonomy of some named coryneform bacteria. J. Gen. Microbiol. 56:195-214.

13. Fiedler, F., and O. Kandler. 1973. Die Mureintypen in der Gattung Cellulomonas Bergey et al. Arch. Mikrobiol. 89:41-50.

14. Han, Y. W. 1982. Nutritional requirements and growth of a Cellulomonas species on cellulosic substrates. J. Ferment. Technol. 60:99-104.

15. Harper, J. J., and G. H. G. Davis. 1979. Two-dimensional thin-layer chromatography for amino acid analysis of bacterial cell walls. Int. J. Syst. Bacteriol. 29:56-58.

16. Holdeman, L. V., E. P. Cato, and W. E. C. Moore (ed.). 1977. Anaerobe laboratory manual, 4th ed. Virginia Polytechnic Institute and State University, Blacksburg.
17. Holding, A. J., and J. G. Collee. 1971. Routine biochemical tests, p. 1-32. In J. R. Norris and D. W. Ribbons (ed.), Methods in microbiology, 6A. Academic Press, Inc. (London), Ltd., London.

18. Hungate, R. E. 1950 . The anaerobic mesophilic cellulolytic bacteria. Bacteriol. Rev. 14:1-49.

19. Hungate, R. E. 1969. A roll tube method for cultivation of strict anaerobes, p. 117-132. In J. R. Norris and D. W. Ribbons (ed.), Methods in microbiology, 3B. Academic Press, Inc. (London), Ltd., London.

20. Johnson, J. L., and E. J. Ordal. 1968. Deoxribonucleic acíd homology in bacterial taxonomy: effect of incubation temperature on reaction specificity. J. Bacteriol. 95:893-900.

21. Lang, E., and H. Lang. 1972. Spezifische Farbreaktion zum direkten Nachweis der Ameisensäure. Z. Anal. Chem. 260:8-10.

22. Lechevalier, M. P. 1972. Description of a new species, Oerskovia xanthineolytica, and emendation of Oerskovia Prauser et al. Int. J. Syst. Bacteriol. 22:260-264.

23. Mandel, M., and J. Marmur. 1968. Use of ultraviolet absorbance-temperature profile for determining the guanine plus cytosine content of DNA. Methods Enzymol. 12B:195-206.

24. Ryter, A., and F. Jacob. 1966. Etude morphologique de la liaison du noyau à la membrane chez Escherichia coli et chez les protoplastes de Bacillus subtilis. Ann. Inst. Pasteur (Paris) 110:810-812.

25. Schleifer, K. H., and O. Kandler. 1972. Peptidoglycan types of bacterial cell walls and their taxonomic implications. Bacteriol. Rev. 36:407-477.

26. Shelef, G., G. Oron, R. Moraine, and M. Ronen. 1980. Combined treatment and disposal of municipal solid wastes (MSW and wastewaters sludge). Ingegneria ambiontale 9:199-207.

27. Stackebrandt, E., M. Häringer, and K. H. Schleifer. 1980. Molecular genetic evidence for the transfer of Oerskovia species into the genus Cellulomonas. Arch. Microbiol. 127:179-185.

28. Stackebrandt, E., and O. Kandler. 1974. Biochemischtaxonomische Untersuchungen an der Gattung Cellulomonas. Zentralbl. Bakteriol. Parasitenkd. Infektionskr. Hyg. Abt. 1 Orig. Reihe A 228:128-135.

29. Stackebrandt, E., and O. Kandler. 1979. Taxonomy of the genus Cellulomonas, based on phenotypic characters and deoxyribonucleic acid-deoxyribonucleic acid homology, and proposal of seven neotype strains. Int. J. Syst. Bacteriol. 29:273-282.

30. Stackebrandt, E., and O. Kandler. 1980. Cellulomonas cartae sp. nov. Int. J. Syst. Bacteriol. 30:186-188.

31. Stackebrandt, E., H. Seiler, and K. H. Schleifer. 1982. Union of the genera Cellulomonas Bergey et al. and Oerskovia Prauser et al. in a redefined genus Cellulomonas. Zentralbl. Bakteriol. Parasitenkd. Infektionskr. Hyg. Abt. 1 Orig. Reihe A 3:401-409.

32. Staneck, J. L., and G. D. Roberts. 1974. Simplified approach to identification of aerobic actinomycetes by thin-layer chromatography. Appl. Microbiol. 28:226-231.

33. Stoppok, W., P. Rapp, and F. Wagner. 1982. Formation, location, and regulation of endo-1,4- $\beta$-glucanases and $\beta$ glucosidases from Cellulomonas uda. Appl. Environ. Microbiol. 44:44-53.

34. Stuart, H. R., and P. E. Pease. 1972. A numerical study on the relationship of Listeria and Erysipelothrix. J. Gen. Microbiol. 73:551-565.

35. Walter, D. K., and C. Rines. 1980. Refuse conversion to methane (RefCOM): a proof of concept anaerobic digestion facility, p. 85-92. In Proceedings, 1980 National Waste Processing Conference. American Society of Mechanical Engineers, New York.

36. Wiegel, J. 1981. Distinction between the gram reaction and the gram type of bacteria. Int. J. Syst. Bacteriol. 31:88.

37. Yamada, K., and K. Komagata. 1970. Taxonomic studies on coryneform bacteria. III. DNA base composition of coryneform bacteria. J. Gen. Appl. Microbiol. 16:215-224.

38. Yamada, Y., G. Inouye, Y. Tahara, and K. Kondô. 1976. The menaquinone system in the classification of coryneform and nocardioform bacteria and related organisms. J. Gen. Appl. Microbiol. 22:203-214. 